\title{
Transcription Factor ETV6
}

National Cancer Institute

\section{Source}

National Cancer Institute. Transcription Factor ETV6. NCI Thesaurus. Code C17798.

Transcription factor ETV6 (452 aa, $\sim 53 \mathrm{kDa}$ ) is encoded by the human ETV6 gene. This protein plays a role in transcriptional repression. 